\section{Association of adverse oral health outcomes with socioeconomic inequalities and dental needs in Brazilian adolescents}

\author{
A associação entre desfechos adversos de \\ saúde bucal e desigualdades socioeconômicas \\ e necessidades odontológicas em adolescentes \\ brasileiro
}

\section{La asociación entre resultados adversos de salud bucal y desigualdades socioeconómicas y necesidades odontológicas en adolescentes brasileños}




\section{Introduction}

Indices and indicators are essential tools for evaluating factors that influence health levels or affect trends in population health status and public policy interventions ${ }^{1}$. Methodological issues concerning the components or use of health indices and indicators should consider, for example, target population, validity and reliability, ability to monitor effects over time, and appropriateness and applicability for health practitioners 2,3,4. Further, health indices and indicators can be classified according to their function into three non-exclusive categories: diagnostic (clinical measures, e.g., blood pressure measurement), prognostic (e.g., scales), and assessment (changes to diagnostic or prognostic measures over time) 5 .

From a population perspective, oral health conditions are commonly evaluated based on isolated indices, e.g., caries, periodontal problems, and occlusion conditions ${ }^{6}$. The literature also cites multidimensional measures that combine two or more oral conditions in the same measure; these multidimensional measures originated from studies in the 1980s and 1990s, focus on adults and elders, and are in the initial stages of development and refinement in terms of validity 7.

Nevertheless, based on the 2010 Global Burden of Disease Study (GBD), oral diseases contributed to an increase of nearly $21 \%$ in the global burden of diseases in the 1990s and 2010s 8 . Untreated caries in permanent teeth was the most prevalent condition among the estimated diseases; severe periodontitis ranked sixth in frequency, whereas tooth loss came in $36^{\text {th }}$ place ${ }^{8}$. Studies have cited significant changes in the prevalence and severity of caries and periodontal diseases related to childhood and adolescence, with a significant increase at age 12 and from 15 to 19 years, indicating that adolescents require special attention $9,10,11,12$.

Estimate of a population's burden of disease enables the assessment of population health status and subsidizes the definition of research priorities, policy development, and resource provision 13 . The simultaneous increased prevalence and severity of oral problems, currently identified in adolescents, suggest that some of these adverse outcomes may be more interrelated than others. This study thus aimed to explore the relations between adverse oral health outcomes in adolescents, according to oral indicators derived from specific indices commonly recommended for oral health surveys 14 , and to describe their distribution according to socioeconomic characteristics, demographics, and selfreported oral health needs and problems.

\section{Methods}

The database was obtained from the 2010 Brazilian National Oral Health Survey (SBBrazil 2010), which also includes information on adolescents from 15 to 19 years of age 15 .

\section{SB Brazil 2010}

The SBBrazil $2010{ }^{15}$ was conducted among individuals in 177 Brazilian municipalities. The population comprised children, adolescents, adults, and elderly (age range 5 to 74 years), distributed across 5 age groups or specific ages as follows: $5,12,15-19,35-44$, and $65-74$ years. The sampling plan included state capitals, the Federal District, and municipalities in the interior of the country's five major regions (North, Northeast, Central, Southeast, and South). The two-stage cluster sampling plan included: (a) the municipality for the interior and (b) a census tract for the state capitals. Data were collected during one single visit to the participants' home. For sample size calculation, the coefficient of variation did not exceed 15\%, whereas the minimum number of interviews per demographic domain was 250; estimated prevalence of oral health problems was expected to exceed $10 \%$, corrected for design effect $($ deff $=2$ ). Additional details on the sampling plan have been published previously 16. The final sample consisted of approximately 38,000 people, including 5,445 adolescents aged 15 to 19 years.

Adverse oral health outcomes in adolescents were evaluated according to the criteria of the 1997 World Health Organization (WHO) manual 14, as follows: the decayed, missing, and filled teeth (DMFT) index and need for caries treatment; the community periodontal index (CPI), with bleeding and dental calculus and deep periodontal pockets collected separately; the dental aesthetic index (DAI); 
and the use of and need for dental prostheses. The questionnaire was administered face-to-face and included information related to the major regions (North, Northeast, Southeast, South, and Central), age (in years), sex, monthly household income in the official Brazilian currency (BRL) and analyzed in categories (from BRL 0.00 to BRL 250.00, BRL 251.00 to BRL 500.00, BRL 501.00 to BRL 1,500.00, BRL 1,501.00 to BRL 2,500.00, BRL 2,501.00 to BRL 4,500.00, BRL 4,501.00 to BRL 9,500.00, and over BRL 9,500.00), and schooling (in completed years) of the participants. In addition, self-rated oral health was assessed through questions on perceived dental treatment need (yes or no), toothache in the previous six months (yes or no); need for prosthesis (yes or no), and self-rated oral health (very satisfied, satisfied, neither satisfied nor dissatisfied, dissatisfied, or very dissatisfied).

The fieldwork team included an examiner (dentist) and a data recorder. Practical and theoretical training was performed for at least 32 hours including approximately one thousand fieldwork teams who worked in the 177 municipalities included in the sample. Two pilot studies were conducted in two cities in the South and Northeast of Brazil 16. Intra-observer concordance calibration was not reported. Inter-observer reliability was estimated by the kappa coefficient, with a minimum acceptable value of 0.65 through the consensus technique 17 in order to standardize dental assessments among the selected examiners. Further information regarding methodological aspects of the survey can be found elsewhere 16 .

The SBBrazil 2010 project followed the standards set by the Declaration of Helsinki and was approved by the Ethics Research Committee of the Ministry of Health, record n. 15,498, January 7, 2010. A written informed consent form approved by the Ethics Research Committee was signed by all participants or by the parents/guardians of all participants under 18 years of age.

\section{Variables and statistical analysis}

A descriptive analysis of the findings from SBBrazil 2010 was conducted according to oral morbidities, socioeconomic characteristics, demographics, and self-reported oral health needs.

The study included the following adverse clinical oral health outcomes: tooth decay (caries, decayed/filled, and filled) and tooth loss due to caries, dental trauma, periodontal problems, congenital disorders, and orthodontic factors; upper and lower anterior tooth loss due to aesthetic reasons, based on the DAI index, was also considered part of this indicator, as were indicators of periodontal status and those related to occlusion problems 14 . Over $88 \%$ of adolescents had one or two components of the DAI index with missing values. For these components, a value of "zero" was attributed, since this procedure had no significant impact on the study results.

\section{Data reduction analysis}

A polychoric correlation matrix containing all the above-mentioned adverse oral health outcomes was estimated. Variables that showed no significant variation, and therefore did not show moderate correlation $(>0.4)$ with the remaining variables 18 , were removed from the matrix. The excluded variables were: number of sound teeth and count of CPI sextants with deep periodontal pockets, as well as anterior open bite.

The set of clinical adverse oral health outcomes was summarized through principal component analysis 19 . Bartlett's test of sphericity and, for the matrix as a whole, a measure of sampling adequacy (MSA), were estimated. The Kaiser-Meyer-Olkin test (KMO) was applied to the variables separately, in such a way that those with values above 0.4 were selected 18 . The above-mentioned tests were then repeated, this time excluding all variables that failed to meet the criteria in the first evaluation.

The number of components to be retained was determined by using the Akaike information criterion (AIC), the Bayesian information criterion (BIC), as well as the Scree test. Promax oblique rotations were done to verify the redistribution of variances 18; no cross loadings were observed among the components. The resulting components were named according to the oral indicator with the highest loading on its respective component, and the scores for the components were estimated. 
The mean scores resulting from the analyses were compared according to demographic characteristics (major region, sex, age) and socioeconomic conditions (monthly household income in BRL: from BRL 0.00 to BRL 500.00, BRL 501.00 to BRL 1,500.00, BRL 1,501.00 to BRL 4,500.00, and over BRL 4,500.00). In this national survey, schooling was defined as the number of school years completed, ranging from zero (illiterate) to 15 (undergraduate studies completed). The age-grade variable, created according to the total number of years of study, described the relationship between the ideal number of years of study at a specific age and the total years of study effectively completed by the participant, which was called the age-grade level (Ministério da Saúde. Edudata Brasil: sistema brasileiro de estatísticas da educação. http://www.edudatabrasil.inep.gov.br/, accessed on 20/Mar/2013). According to Brazilian government guidelines, the ideal age for starting primary school is 7 years; at 15 years, the ideal number of school years completed is 8 , and so on. At 19 years, the ideal number of years of study completed is 12 . Thus, if a 19 -year-old has completed only 8 years of schooling, there is a delay of 4 years in the recommended years of schooling. Based on the variable age-grade level, the sample was classified into four groups: above average, ideal, 1-2 years of delay, and 3 or more years of delay. Self-reported oral health indicators, especially self-rated oral health, were reclassified into three categories: very satisfied/satisfied, neither satisfied nor dissatisfied, and dissatisfied/very dissatisfied.

Eleven 15-year-olds with 13 to 15 years of schooling, nine 16-year-olds with 14 or 15 years of schooling, and seven 17-year-olds with 15 years of schooling were excluded from the study. The analyses were performed by considering the multistage sampling design and sample weights using Stata version 9.0 (StataCorp LP, College Station, USA).

\section{Results}

A polychoric correlation matrix was estimated, initially including 15 eligible variables. The highest correlations were observed among periodontal and DAI conditions: crowding, maxillary and mandibular irregularities, incisal diastema, and incisal spaces (Table 1).

The correlations among variables were statistically significant based on Bartlett's test $(\mathrm{p}<0.001)$, and the MSA value was 0.7. After the KMO test, the following oral indicators were retained: number of decayed, decayed/filled, and filled teeth; tooth loss; number of CPI sextants with bleeding, dental calculus, and shallow periodontal pockets; crowding; maxillary and mandibular irregularities; incisal diastema; and incisal spaces. The correlation matrix was shown by Bartlett's test of sphericity to be statistically significant $(\mathrm{p}<0.001)$, and the MAS value was 0.7 . According to the principal component analysis, the first two components explained $20 \%$ and $16 \%$ of the total variance, respectively; the highest loadings on component 1 were attributed to crowding and maxillary and mandibular irregularities, whereas those on component 2 were related to indicators of periodontal problems (Table 2).

After oblique rotation, the correlation between the first and second components was 0.8 . The highest loadings on component 1 were attributed to indicators of periodontal problems: 0.5 for dental calculus and bleeding and 0.4 for shallow periodontal pockets. For component 2 , the highest loadings were for crowding (0.6) and maxillary and mandibular irregularities (0.5) (Table 3).

According to the survey, 52\% of the adolescents lived in North and Northeast Brazil, and most of them were female. Modal age was 15 years (27\%). More than two thirds of the adolescents had a monthly family income below BRL $1,500.00$ and more than 9 years of schooling. Over two thirds reported dental treatment needs and no dental pain in the previous six months. Dissatisfaction with dental and oral health was reported by $44 \%$ of the adolescents, whereas $5 \%$ cited the need for a dental prosthesis. Regarding occlusal and aesthetic conditions, over 95\% had no anterior tooth loss. About $42 \%$ had crowding in at least one incisal segment and maxillary and mandibular irregularities of 1 and $3 \mathrm{~mm}$. Approximately $80 \%$ of the sample showed no incisal spaces or incisal diastema, and more than $90 \%$ did not have anterior open bite and overjet. About $85 \%$ of the adolescents had more than 20 teeth without caries, and 23\% had at least one missing tooth. Regarding periodontal conditions, 
Table 1

Polychoric correlation matrix according to oral conditions indicators in adolescents from 2010 Brazilian Oral Health Survey $(N=5,445)$.

\begin{tabular}{|c|c|c|c|c|c|c|c|c|c|c|c|c|c|c|c|}
\hline $\begin{array}{l}\text { Varia- } \\
\text { bles }\end{array}$ & $\begin{array}{l}\text { Deca- } \\
\text { yed * }\end{array}$ & $\begin{array}{l}\text { Deca- } \\
\text { yed/ } \\
\text { Filled * }\end{array}$ & $\begin{array}{l}\text { Fil- } \\
\text { led * }\end{array}$ & $\begin{array}{l}\text { Tooth } \\
\text { loss * }\end{array}$ & $\begin{array}{c}\text { Blee- } \\
\text { ding } \\
* *\end{array}$ & $\begin{array}{l}\text { Dental } \\
\text { calcu- } \\
\text { lus ** }\end{array}$ & $\begin{array}{c}\text { Shallow } \\
\text { perio- } \\
\text { dontal } \\
\text { pocket ** }\end{array}$ & $\begin{array}{c}\text { Crow- } \\
\text { ding }\end{array}$ & $\begin{array}{l}\text { Inci- } \\
\text { sal } \\
\text { spa- } \\
\text { ces }\end{array}$ & $\begin{array}{c}\text { Incisal } \\
\text { dias- } \\
\text { tema }\end{array}$ & $\begin{array}{c}\text { Maxil- } \\
\text { lary } \\
\text { irregu- } \\
\text { larity }\end{array}$ & $\begin{array}{l}\text { Mandi- } \\
\text { bular } \\
\text { irregu- } \\
\text { larity }\end{array}$ & $\begin{array}{c}\text { Maxil- } \\
\text { lary } \\
\text { over- } \\
\text { jet }\end{array}$ & $\begin{array}{c}\text { Mandi- } \\
\text { bular } \\
\text { over- } \\
\text { jet }\end{array}$ & $\begin{array}{c}\text { Molar } \\
\text { rela- } \\
\text { tion- } \\
\text { ship }\end{array}$ \\
\hline $\begin{array}{l}\text { Deca- } \\
\text { yed * }\end{array}$ & 1.00 & & & & & & & & & & & & & & \\
\hline $\begin{array}{l}\text { Decayed/ } \\
\text { Filled* }\end{array}$ & 0.08 & 1.00 & & & & & & & & & & & & & \\
\hline Filled * & -0.12 & 0.10 & 1.00 & & & & & & & & & & & & \\
\hline $\begin{array}{l}\text { Tooth } \\
\text { loss * }\end{array}$ & 0.10 & 0.04 & 0.10 & 1.00 & & & & & & & & & & & \\
\hline $\begin{array}{l}\text { Blee- } \\
\text { ding ** }\end{array}$ & 0.24 & 0.10 & -0.01 & 0.05 & 1.00 & & & & & & & & & & \\
\hline $\begin{array}{l}\text { Dental } \\
\text { calcu- } \\
\text { lus ** }\end{array}$ & 0.28 & 0.09 & -0.06 & 0.04 & $\begin{array}{l}0.67 \\
\star * *\end{array}$ & 1.00 & & & & & & & & & \\
\hline $\begin{array}{l}\text { Shallow } \\
\text { perio- } \\
\text { dontal } \\
\text { poc- } \\
\text { ket ** }\end{array}$ & 0.23 & 0.10 & -0.01 & 0.10 & $\begin{array}{l}0.58 \\
\star \star \star\end{array}$ & $0.54 * * *$ & 1.00 & & & & & & & & \\
\hline Crowding & 0.07 & 0.02 & 0.02 & -0.08 & 0.18 & 0.13 & 0.02 & 1.00 & & & & & & & \\
\hline $\begin{array}{l}\text { Incisal } \\
\text { spaces }\end{array}$ & 0.03 & 0.01 & -0.06 & 0.04 & 0.05 & 0.05 & 0.05 & -0.31 & 1.00 & & & & & & \\
\hline $\begin{array}{l}\text { Incisal } \\
\text { diastema }\end{array}$ & 0.03 & 0.04 & -0.05 & 0.01 & -0.01 & 0.03 & 0.04 & -0.28 & $\begin{array}{l}0.73 \\
\star * *\end{array}$ & 1.00 & & & & & \\
\hline $\begin{array}{l}\text { Maxillary } \\
\text { irregula- } \\
\text { rity }\end{array}$ & 0.08 & 0.04 & 0.01 & -0.02 & 0.14 & 0.11 & 0.06 & $\begin{array}{l}0.59 \\
\star \star \star\end{array}$ & -0.13 & -0.08 & 1.00 & & & & \\
\hline $\begin{array}{l}\text { Mandi- } \\
\text { bular } \\
\text { irregu- } \\
\text { larity }\end{array}$ & 0.05 & 0.01 & 0.02 & -0.05 & 0.12 & 0.13 & 0.06 & $\begin{array}{l}0.60 \\
\star \star \star\end{array}$ & -0.15 & -0.11 & $\begin{array}{l}0.45 \\
\star \star \star\end{array}$ & 1.00 & & & \\
\hline $\begin{array}{l}\text { Maxillary } \\
\text { overjet }\end{array}$ & -0.03 & -0.04 & 0.01 & 0.02 & 0.11 & 0.07 & 0.05 & 0.21 & 0.01 & -0.01 & 0.23 & 0.18 & 1.00 & & \\
\hline $\begin{array}{l}\text { Mandi- } \\
\text { bular } \\
\text { overjet }\end{array}$ & 0.12 & 0.01 & 0.08 & 0.07 & 0.12 & 0.08 & -0.02 & 0.04 & 0.09 & 0.09 & 0.09 & 0.02 & -0.75 & 1.00 & \\
\hline $\begin{array}{l}\text { Molar } \\
\text { relation- } \\
\text { ship }\end{array}$ & 0.11 & -0.00 & 0.03 & 0.06 & 0.16 & 0.15 & 0.10 & 0.24 & 0.09 & 0.03 & 0.21 & 0.18 & 0.11 & 0.29 & 1.00 \\
\hline
\end{tabular}

* Count of teeth with;

** Count of periodontal community index (CPI) sextants with;

$\star * *$ Loads of variables with values above 0.40 .

approximately $34 \%$ showed bleeding or dental calculus in at least one to three teeth as a major condition. Prevalence of shallow periodontal pockets was found in $10 \%$ of the sample, but most of the adolescents had no deep periodontal pockets.

Adolescents with lower family income had higher mean scores for periodontal problems and occlusal disorders compared with those with higher income. Lower mean scores for occlusal disorder indicators were found in adolescents from South Brazil, those without a delay in schooling, those 
Table 2

Principal components load values prior to rotation.

\begin{tabular}{|c|c|c|c|c|}
\hline \multirow[t]{2}{*}{ Variables } & \multicolumn{4}{|c|}{ Principal component analysis * } \\
\hline & Component 1 ** & p-value & Component $2 * * *$ & p-value \\
\hline Decayed \# & 0.23 & $<0.001$ & 0.27 & $<0.001$ \\
\hline Decayed/Filled \# & 0.10 & $<0.001$ & 0.14 & $<0.001$ \\
\hline Filled \# & -0.01 & 0.571 & -0.08 & 0.001 \\
\hline Tooth loss \# & 0.00 & 0.886 & 0.14 & $<0.001$ \\
\hline Bleeding \#\# & 0.37 & $<0.001$ & 0.38 & $<0.001$ \\
\hline Dental calculus \#\# & 0.36 & $<0.001$ & 0.40 & $<0.001$ \\
\hline Shallow periodontal pockets \#\# & 0.24 & $<0.001$ & 0.37 & $<0.001$ \\
\hline Crowding & 0.46 & $<0.001$ & -0.33 & $<0.001$ \\
\hline Incisal spaces & -0.13 & $<0.001$ & 0.33 & $<0.001$ \\
\hline Incisal diastema & -0.10 & $<0.001$ & 0.29 & $<0.001$ \\
\hline Maxillary irregularity & 0.43 & $<0.001$ & -0.25 & $<0.001$ \\
\hline Mandibular irregularity & 0.43 & $<0.001$ & -0.27 & $<0.001$ \\
\hline
\end{tabular}

* Bartlett sphericity test $p<0.001$ and measure of sampling adequacy $(M S A)=0.66$;

** Eigenvalue component $1=2.35(20 \%)$;

*** Eigenvalue component $2=1.91(16 \%)$;

\# Count of teeth with;

\#\# Count of periodontal community index (CPI) sextants with.

Table 3

Retained components' load values and oral indicators' scores after oblique rotation.

\begin{tabular}{lcccc}
\hline Variables & Component 1 * & Score & Component 2 ** & Score \\
\hline Decayed *** & 0.36 & 0.35 & 0.03 & 0.00 \\
Decayed/Filled *** & 0.17 & 0.17 & -0.00 & -0.02 \\
Filled *** & -0.01 & -0.07 & 0.04 & 0.04 \\
Tooth loss *** & 0.11 & 0.11 & -0.08 & -0.09 \\
Bleeding \# & 0.53 & 0.52 & 0.09 & 0.04 \\
Dental calculus \# & 0.54 & 0.54 & 0.06 & -0.01 \\
Shallow periodontal pockets \# & 0.44 & 0.44 & -0.02 & -0.57 \\
Crowding & 0.05 & 0.00 & 0.57 & -0.32 \\
Incisal spaces & 0.17 & 0.19 & -0.30 & -0.26 \\
Incisal diastema & 0.15 & 0.17 & -0.25 & 0.50 \\
Maxillary irregularity & 0.09 & 0.05 & 0.51 & 0.50 \\
Mandibular irregularity & 0.07 & 0.03 & 0 \\
\hline
\end{tabular}

* Eigenvalue components after rotation: component $1=2.22$ (19\%);

** Eigenvalue components after rotation: component $2=2.11(18 \%)$;

$\star \star *$ Count of teeth with;

\# Count of periodontal community index (CPI) sextants with.

Note: correlations among components $=0.82$. 
who reported no need for treatment, and those with no toothache in the previous six months. Among adolescents who reported dental treatment needs, higher mean scores for periodontal problems were observed. Those who reported dissatisfaction with their dental and oral health had higher mean scores for all indicators of periodontal conditions and occlusal disorders. Among those who reported the need for a dental prostheses, the mean for occlusal disorder indicators was three times higher than for periodontal condition indicators; the mean for the set of periodontal indicators was at least four times lower among adolescents who reported the need for a dental prosthesis (Table 4).

\section{Discussion}

Higher correlations were observed among occlusal disorders and periodontal conditions. Higher means for the set of oral indicators for both components were found among lower income adolescents and those who reported dissatisfaction with health of teeth and mouth. A lower average score was also observed among adolescents who lived in Southeast Brazil, as well as in those who had no schooling delay, no dental treatment needs, no toothache in the previous six months, and no need for prosthesis.

Based on the set of correlated adverse oral health outcomes, lower loadings for both components were obtained specifically for count of decayed teeth, decayed/filled teeth, and tooth loss. The low values for these indicators could be attributed to their low variability in the sample, given that the proportion of adolescents with no decayed/filled teeth, more than 20 sound teeth, or no missing teeth exceeded $85 \% 10$.

Meanwhile, higher loadings were observed for crowding, followed by maxillary and mandibular irregularities. According to prevalence of occlusal disorders in this national survey, over $42 \%$ of the adolescents had at least one crowded segment or mandibular/maxillary irregularities 10, confirming findings in the literature 20,21. However, the presence of other DAI conditions, for example, $60 \%$ of adolescents had overjet of 1 to $3 \mathrm{~mm}$ and $40 \%$ presented at least a half-cusp deviation 10 , did not show sufficient correlation in the analyses.

Moreover, periodontal conditions played an important role among the correlated oral indicators in Brazilian adolescents. This finding can be attributed to the greater variability of these conditions in this age group, considering that the proportions of adolescents who had CPI sextants with bleeding, dental calculus, and shallow periodontal pockets in 2003 were, respectively, 19\%, 33\%, and $1 \% 22$ and that at least $35 \%$ had current bleeding or dental calculus, and that almost $10 \%$ had shallow periodontal pockets as a common periodontal problem 10 . The same results on bleeding conditions and dental calculus for ages 15 to 19 years can be found in the literature 23 .

Higher mean scores of correlated periodontal problems and occlusal disorders were found among adolescents with lower income. Although this study does not aim to analyze social inequalities in health, the findings point in the same direction as the literature 23,24,25,26. Additionally, adolescents with more schooling delay had higher mean scores for correlated occlusal disorders. Despite differences among distal factors associated with occlusion conditions, severe malocclusion or the highest prevalence of DAI indicators were associated with lower income or public school education 20,26. Higher mean scores for the set of oral indicators for both components among adolescents dissatisfied with their oral health were observed. Regarding occlusal disorders, adolescents who reported satisfaction with their dental and oral health had lower mean scores compared with those who reported otherwise. Positive associations among adolescents who reported oral health needs and oral problems were found in the literature 27,28 .

Principal component analysis is a multivariate statistical technique of interdependence that proposes that a set of initial variables could create new synthetic variables by linear combination, allowing simultaneous information and theoretical interpretations for the phenomenon studied 19 . However, the literature points to limitations in multivariate techniques of data reduction, for example, the subjectivity of the decision based on the components extracted, the matrix notation technique choices, and the plausibility of the results obtained 18,19 .

Despite published multidimensional measures in the literature 5 , this study sought to analyze adverse oral health outcomes based on a national survey, collected according to specific indices recommended by the WHO ${ }^{14}$. The findings showed low correlations among caries and periodontal and 


\section{Table 4}

Components' mean scores after oblique rotation according to demographic, socioeconomic, and self-rated oral health in adolescents in the 2010 Brazilian Oral Health Survey $(\mathrm{N}=5,445)$.

\begin{tabular}{|c|c|c|c|c|}
\hline & \multicolumn{4}{|c|}{ Components } \\
\hline & $\begin{array}{l}\text { Periodontal } \\
\text { conditions } \\
\text { component }\end{array}$ & $95 \% \mathrm{Cl}$ & $\begin{array}{l}\text { Occlusal } \\
\text { disorders } \\
\text { component }\end{array}$ & $95 \% \mathrm{Cl}$ \\
\hline \multicolumn{5}{|l|}{ Brazilian regions [N $=5,445]$} \\
\hline North & 0.03 & $-0.14 ; 0.20$ & 0.78 & $0.56 ; 1.00$ \\
\hline Northeast & 0.01 & $-0.14 ; 0.15$ & 0.02 & $-0.15 ; 0.19$ \\
\hline Southeast & 0.09 & $-0.11 ; 0.29$ & -0.28 & $-0.47 ;-0.09$ \\
\hline South & 0.05 & $-0.19 ; 0.29$ & -0.22 & $-0.41 ;-0.03$ \\
\hline Central & -0.04 & $-0.29 ; 0.22$ & 0.03 & $-0.16 ; 0.22$ \\
\hline \multicolumn{5}{|l|}{$\operatorname{Sex}[N=5,445]$} \\
\hline Male & 0.06 & $-0.11 ; 0.23$ & -0.08 & $-0.24 ; 0.07$ \\
\hline Female & 0.06 & $-0.09 ; 0.22$ & -0.15 & $-0.32 ; 0.01$ \\
\hline \multicolumn{5}{|l|}{ Age (years) [N = 5,445] } \\
\hline 15 & 0.16 & $-0.11 ; 0.44$ & -0.09 & $-0.29 ; 0.10$ \\
\hline 16 & 0.11 & $-0.06 ; 0.27$ & -0.26 & $-0.45 ;-0.07$ \\
\hline 17 & 0.09 & $-0.15 ; 0.33$ & -0.23 & $-0.42 ;-0.05$ \\
\hline 18 & -0.01 & $-0.21 ; 0.19$ & -0.05 & $-0.26 ; 0.15$ \\
\hline 19 & -0.07 & $-0.30 ; 0.16$ & 0.01 & $-0.24 ; 0.27$ \\
\hline \multicolumn{5}{|c|}{ Monthly household income in BRL (USD) [N = 5,125] } \\
\hline$\leq 500(\leq 185)$ & 0.20 & $0.00 ; 0.40$ & 0.36 & $0.14 ; 0.58$ \\
\hline $501-1,500(186-556)$ & 0.15 & $-0.01 ; 0.31$ & -0.03 & $-0.21 ; 0.14$ \\
\hline $1,501-4,500(557-1,667)$ & -0.12 & $-0.34 ; 0.10$ & -0.45 & $-0.63 ;-0.28$ \\
\hline$>4,500(>1,667)$ & -0.41 & $-0.74 ;-0.08$ & -0.62 & $-0.86 ;-0.38$ \\
\hline \multicolumn{5}{|l|}{ Age-grade level $[N=5,097]$} \\
\hline Above & 0.15 & $-0.10 ; 0.40$ & -0.50 & $-0.64 ;-0.36$ \\
\hline Ideal & 0.06 & $-0.12 ; 0.25$ & -0.10 & $-0.28 ; 0.08$ \\
\hline 1-2 years of delay & 0.10 & $-0.08 ; 0.27$ & 0.13 & $-0.16 ; 0.42$ \\
\hline 3 or more years of delay & -0.14 & $-0.40 ; 0.11$ & 0.58 & $0.30 ; 0.87$ \\
\hline \multicolumn{5}{|c|}{ Perceived dental treatment need $[N=5,241]$} \\
\hline No & -0.10 & $-0.29 ; 0.09$ & -0.46 & $-0.62 ;-0.30$ \\
\hline Yes & 0.18 & $0.04 ; 0.32$ & 0.05 & $-0.12 ; 0.22$ \\
\hline \multicolumn{5}{|c|}{ Toothache in the previous six months $[N=5,427]$} \\
\hline No & 0.02 & $-0.12 ; 0.17$ & -0.26 & $-0.39 ;-0.13$ \\
\hline Yes & 0.18 & $-0.01 ; 0.37$ & 0.29 & $0.08 ; 0.51$ \\
\hline \multicolumn{5}{|l|}{ Self-rated oral health $[N=5,382]$} \\
\hline Very satisfied/Satisfied & -0.12 & $-0.27 ; 0.03$ & -0.36 & $-0.49 ;-0.23$ \\
\hline Neither satisfied/Nor dissatisfied & 0.18 & $-0.08 ; 0.43$ & -0.03 & $-0.25 ; 0.19$ \\
\hline Dissatisfied/Very dissatisfied & 0.36 & $0.16 ; 0.56$ & 0.32 & $0.11 ; 0.54$ \\
\hline \multicolumn{5}{|c|}{ Perceived need for prosthesis [N = 5,261] } \\
\hline No & 0.09 & $-0.04 ; 0.22$ & -0.14 & $-0.28 ;-0.01$ \\
\hline Yes & -0.41 & $-0.81 ;-0.02$ & 0.42 & $0.03 ; 0.80$ \\
\hline
\end{tabular}

95\% Cl: 95\% confidence interval. 
occlusion conditions, which could differ from other studies. This is a large national survey conducted by the Brazilian Ministry of Health and considered an important component of the National Policy on Oral Health. Although the calibration manual has reported that the process of intra-observer agreement should have been performed during the fieldwork process, intra-observer concordance results were not publicly available.

On the other hand, health outcomes can be used as management tools for planning and directing resources 2 and monitoring inequalities in health profiles 16 . In this study, significant correlations were identified among oral problems, such as bleeding, dental calculus, and shallow periodontal pockets in the first component, as well as crowding and anterior irregularities in the second component; the accumulation of this set of oral indicators was observed, particularly among adolescents with lower family income and schooling delay. This emphasized that reversible oral conditions, such as bleeding and dental calculus, were highly correlated. In addition, the correlation between crowding and anterior irregularities in adolescents suggested that, when planning action for aesthetic disorders, such information could be considered.

Therefore, correlations among oral indicators could be a co-adjuvant in population oral health surveys, even among other age groups. They offer an overview of correlated oral health problems, identifying their accumulation and indicating research priorities in integrating oral health conditions. In turn, these correlations may be helpful in planning oral health services and monitoring oral conditions over time.

\section{Contributors}

D. R. Figueiredo and J. L. Bastos contributed to the study conception and design, data analysis and interpretation, and drafting of the manuscript. $\mathrm{K}$. G. Peres contributed to study design, data analysis and interpretation, and critical revision of the manuscript

\section{Acknowledgments}

The authors wish to thank the Oral Health Division (COSAB) of the Brazilian Ministry of Health for granting access to the database. 


\section{References}

1. World Health Organization. Measurement of levels of health; report of a study group. World Health Organ Tech Rep Ser 1957; 57:3-24.

2. Hunt SM, McEwen J, McKenna SP. Measuring health status. Beckenham: Croom Helm; 1986.

3. Mokkink LB, Terwee CB, Knol DL, Stratford PW, Alonso J, Patrick DL, et al. Protocol of the COSMIN study: consensus-based standards for the selection of health measurement instruments. BMC Med Res Methodol 2006; 6:2.

4. Mokkink LB, Terwee CB, Patrick DL, Alonso J, Stratford PW, Knol DL, et al. The COSMIN checklist for assessing the methodological quality of studies on measurement properties of health status measurement instruments: an international Delphi study. Qual Life Res 2010; 19:539-49.

5. McDowell I. Measuring health: a guide to rating scales and questionnaires. 3rd Ed. New York: Oxford University Press; 2006.

6. World Health Organization. Oral health surveys: basic methods. 5th Ed. Geneva: World Health Organization; 2013.

7. Figueiredo DR, Bastos JL, Silva L, Peres KG. Multidimensional indices of clinical oral conditions from a population perspective: a systematic review. Community Dent Oral Epidemiol 2016; 44:180-7.

8. Marcenes W, Kassebaum NJ, Bernabé E, Flaxman A, Naghavi M, Lopez A, et al. Global burden of oral conditions in 1990-2010: a systematic analysis. J Dent Res 2013; 92:592-7.

9. Arrow P, Brennan D, Spencer AJ. Quality of life and psychosocial outcomes after fixed orthodontic treatment: a 17-year observational cohort study. Community Dent Oral Epidemiol 2011; 39:505-14.

10. Coordenação Geral de Saúde Bucal, Departamento de Atenção Básica, Secretaria de Vigilância em Saúde, Secretaria de Atenção à Saúde, Ministério da Saúde. SBBrasil 2010: Pesquisa Nacional de Saúde Bucal. Resultados principais. Brasília: Ministério da Saúde; 2010.

11. Jamieson LM1, Armfield JM, Roberts-Thomson KF, Sayers SM. A retrospective longitudinal study of caries development in an Australian Aboriginal Birth Cohort. Caries Res 2010; 44:415-20.

12. Tylee A, Haller DM, Graham T, Churchill R, Sanci LA. Youth-friendly primary-care services: how are we doing and what more needs to be done? Lancet 2007; 69:1565-73.

13. Murray CJ, Ezzati M, Flaxman AD, Lim S, Lozano R, Michaud C, et al. GBD 2010: design, definitions, and metrics. Lancet 2012; 380:2063-6.

14. World Health Organization. Oral health surveys: basic methods. 4th Ed. Geneva: World Health Organization; 1997.
15. Coordenação Geral de Saúde Bucal, Departamento de Atenção Básica, Secretaria de Atenção à Saúde, Ministério da Saúde. SBBrasil 2010: Pesquisa Nacional de Saúde Bucal. Projeto técnico. Brasília: Ministério da Saúde; 2009.

16. Roncalli AG, Silva NN, Nascimento AC, Freitas CHSM, Casotti E, Peres KG, et al. Aspectos metodológicos do Projeto SBBrasil 2010 de interesse para inquéritos nacionais de saúde. Cad Saúde Pública 2012; 28 Suppl:S40-57.

17. Frias AC, Antunes JLF, Narvai PC. Reliability and validity of oral health surveys: dental caries in the city of São Paulo, 2002. Rev Bras Epidemiol 2004; 7:144-54.

18. Hair Jr. JF, Black WC, Babin B, Rolph E. Multivariate data analysis. 6th Ed. Porto Alegre: Bookman; 2009.

19. Bouroche JM, Saporta G. Data analysis. Rio de Janeiro: Jorge Zahar Editores; 1982.

20. Frazão P, Narvai PC. Socio-environmental factors associated with dental occlusion in adolescents. Am J Orthod Dentofacial Orthop 2006; 129:809-16.

21. Gabris K, Marton S, Madlena M. Prevalence of malocclusions in Hungarian adolescents. Eur J Orthod 2006; 28:467-70.

22. Coordenação Geral de Saúde Bucal, Departamento de Atenção Básica, Secretaria de Vigilância em Saúde, Ministério da Saúde. SBBrasil 2003: Pesquisa Nacional de Saúde Bucal. Resultados principais. Brasília: Ministério da Saúde; 2004.

23. Antunes JL, Peres MA, Frias AC, Crosato EM, Biazevic MGH. Gingival health of adolescents and the utilization of dental services, state of São Paulo, Brazil. Rev Saúde Pública 2008; 42:191-9.

24. Petersen PE, Ogawa H. The global burden of periodontal disease: towards integration with chronic disease prevention and control. Periodontol 2000 2012; 60:15-39.

25. Jamieson LM, Gunthorpe W, Cairney SJ, Sayers SM, Roberts-Thomson KF, Slade GD. Substance use and periodontal disease among Australian Aboriginal young adults. Addiction 2010; 105:719-26.

26. Peres KG, Frazão P, Roncalli AG. Epidemiological pattern of severe malocclusions in Brazilian adolescents. Rev Saúde Pública 2013; 47:109-17.

27. Peres MA, Peres KG, Frias AC, Antunes JL. Contextual and individual assessment of dental pain period prevalence in adolescents: a multilevel approach. BMC Oral Health 2010; 10:20.

28. Freire MDM, Leles CR, Sardinha LMV, Paludetto Junior M, Malta DC, Peres MA, et al. Dor dentária e fatores associados em adolescentes brasileiros: a Pesquisa Nacional de Saúde do Escolar (PeNSE), Brasil, 2009. Cad Saúde Pública 2012; 28 Suppl:S133-45. 


\section{Resumo}

O estudo explora as relações entre desfechos adversos de saúde oral e variáveis socioeconômicas, demográficas e de saúde oral auto-relatada, $e$ descreve sua distribuição. Foi realizada a análise de componentes principais em dados de adolescentes na Pesquisa Nacional de Saúde Bucal $(N=5.445)$. Foram identificadas cargas mais altas para apinhamento $(0,6)$, irregularidades maxilares e mandibulares $(0,5)$ e contagem de sextantes de indice periodontal comunitário (IPC) com sangramento e cálculo dentário $(0,5)$. As taxas médias de distúrbios periodontais e oclusais foram pelo menos duas vezes mais elevadas nos adolescentes de famílias de baixa renda e naqueles que relataram necessidade de próteses dentárias, assim como, naqueles que relataram insatisfação com sua saúde dental e bucal em geral. Taxas aumentadas de disfunções oclusais estiveram associadas ao atraso escolar e história de dor de dente nos últimos seis meses. As taxas médias sugeriram o acúmulo de pelo menos um dos indicadores negativos de saúde bucal na faixa de renda mais baixa, entre adolescentes com atraso escolar e entre aqueles que relataram necessidade de tratamento odontológico. Os resultados apontam para prioridades de planejamento e monitoramento em função das necessidades de tratamento dentário.

Saúde Bucal; Odontologia em Saúde Pública; Adolescente

\section{Resumen}

El estudio explora las relaciones entre resultados adversos de salud oral y variables socioeconómicas, demográficas y de salud oral auto-informada, $y$ describe su distribución. Se realizó el análisis de componentes principales en datos de adolescentes en la Investigación Nacional de Salud Bucal $(N=5.445)$. Se identificaron cargas más altas para apiñamiento $(0,6)$, irregularidades maxilares $y$ mandibulares $(0,5)$ y cómputo de sextantes de indice periodontal de la comunidad (IPC) con sangramiento y cálculo dentario $(0,5)$. Las tasas medias de problemas periodentales y oclusales fueron por lo menos dos veces más elevadas en los adolescentes de familias de baja renta y en aquellos que relataron necesidades de prótesis dentales, así como, en aquellos que relataron insatisfacción con su salud dental y bucal en general. Tasas aumentadas de disfunciones oclusales estuvieron asociadas al atraso escolar e historia de dolor de dientes durante los últimos seis meses. Las tasas medias sugirieron el acúmulo de por lo menos uno de los indicadores negativos de salud bucal en la franja de renta más baja, entre adolescentes con atraso escolar y entre aquellos que relataron necesidad de tratamiento odontológico. Los resultados apuntan a prioridades de planificación y monitoreo en función de las necesidades de tratamiento dental.

Salud Bucal; Odontología en Salud Pública; Adolescente
Submitted on 20/Dec/2015

Final version resubmitted on 14/Jun/2016

Approved on 24/Jun/2016 